\title{
Learner Autonomy and Internal Locus of Control: Influential Factors in EFL Context
}

\author{
Behnam Aghayani \\ Independent Researcher, Iran \\ *Correspondence: behnam.aghayani@gmail.com
}

\begin{abstract}
Considering the significant role of learner autonomy and internal locus of control in language learning process, the present study attempted to investigate the correlation between EFL learners' autonomy and internal locus of control. To achieve such aim, a sample of 95 Iranian EFL learners both male $(n=33)$ and female $(n=62)$ participated in this study. The instruments used in the present study were learner autonomy questionnaire (Learner Autonomy Perception Questionnaire) and internal locus of control questionnaire (Internal Locus of Control Index). The findings indicated a significant positive correlation among EFL learners' autonomy and their internal locus of control. Moreover, this study highlights the importance of learner autonomy and internal locus of control in the foreign language learning and also aims to raise EFL teachers' awareness of the importance of these two key factors in the EFL context. The suggestions related to the findings of the current study are discussed at the end of study.
\end{abstract}

\section{ARTICLE HISTORY}

Published June 29th 2021

Check for updates

\section{KEYWORDS}

EFL context, EFL Learners, Internal Locus of Control, Learner Autonomy, Locus of Control

\section{ARTICLE LICENCE}

(C) 2021 Universitas Hasanuddin Under the license CC BY-SA 4.0

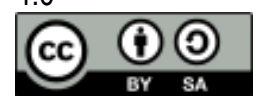

\section{Introduction}

According to Nowicki (2016), the notion of 'locus of control' gained fundamental functions in the realm of learners' academic achievements. Locus of control, according to Latha and Vijayalakshmi (2020), is "the degree of control of people over the output of events happening in the day to day events happening around them" (p. 45). As Stewart (2012) state "locus of control is interwoven with one's "attribution style." Attribution style determines to which forces an individual attributes success" (p. 77). Dividing the category of locus of control into two external and internal sources that internality deals with a cognitive-based feature with the personality and character-trait tone (Reich \& Infurna, 2017), through the review of the literature on the locus of control, it was revealed that the internal locus of control is the key factor that affecting learner's academic achievements (Nowicki, 2016); indeed, students with high level of internal locus of control are more responsible for their own learning (Al Mulhim, 2021) and students with internal locus of control engage in the learning process more than others (Cascio, Botta \& Anzaldi, 2013).

By giving a quick glance on the related literature, it was revealed that individuals' positive internal locus of control and positive academic achievements turned into one of the major research questions which still remained open to be investigated about (Hill, 2011). Moreover, due to the significant impact of the locus of control on people's lives and their attitudes to life-events in both educational and non-academic contexts, this notion "as a personality variable has been more important in recent theoretical and applied researches" (Soleimani, Aghayani \& Ashari, 2018, p. 14). A number of studies reported the effectiveness of locus of control in EFL context in which it influences EFL learners' test anxiety and test scores (Katirayifar \& Rezvani, 2017), affects EFL learners' translation achievement (Irgin \& Öz, 2020), influences EFL learners' preference for vocabulary acquisition (Aghayani \& Soleimani, 2016), improves EFL learners' reading comprehension (Naseri \& Ghabanchi, 2014; Nejabati, 2014), strengthens EFL learners' creativity in writing (Khoshsima \& Izadi, 2015), predicts EFL learners' willingness to communicate (Arkavazi \& Nosratinia, 2018), enhances EFL learners' language achievement (Amini, 2013), and affects EFL learners' reading and writing achievement (Ghonsooly \& Elahi Shirvan, 2011).

The notion of learner autonomy was first proposed and by Holec (1981). Learner autonomy, according to Benson (2013), defined as "the capacity to control one's own learning" (p. 92). In other words, learner autonomy refers to a capacity 
constructed in learners resulting in expanding and enlarging the students' independency in the context of making informed choices instead of acting haphazardly about their own learning processes (Koban-Koç \& Koç, 2016). The ignorance of learner autonomy in the learning environment block learners' way to achieving higher qualified levels of language learning that results in the learners' loss of motivation for the pursuit of foreign language learning, so learner autonomy and the factors affecting it can be considered as one of the significant features which can affect foreign language learning and achievement (Judy Shih, 2021; Kuluşaklı \& Yumru, 2020; Yagcioglu, 2015). Overall, learner autonomy is "a vital indicator of successful language learning" (Chang, 2020, p. 1) and it is "an educational goal of teaching English as a foreign language (Teng, 2019, p. 1). A number of studies reflecting the impact of learner autonomy on EFL learners' English language proficiency (Myartawan, Latief \& Suharmanto, 2013; Melvina \& Julia, 2021) and online learning in EFL context (Ningsih \& Yusuf, 2021; Huang, 2020). The present study aims at investigating the possible correlation between EFL learners' autonomy and internal locus of control.

\section{Review of the Related Literature}

Few studies have been specified to the examination of the correlation between EFL learners' autonomy and internal locus of control. Saadat, Ghasemzadeh, Karami, and Soleimani (2012) explored on the relationship between self-esteem, as the manifestation of learner autonomy, and locus of control among 370 Iranian university students. The finding from their study showed that self-esteem have a positive relationship with internal locus of control. They also found internal locus of control can predict the students' self-esteem.

In another research, Peek (2016) implied the correlation between learner autonomy and language learning locus of control in the context of multilingual learners as experienced language learners. He came to conclusion that the more experienced language learners were, the more they benefit from autonomy and the more they show internal language learning locus of control. This conclusion implies autonomous learners are fundamentally affected by internal locus of control in process of language learning.

More recently, Aghayani and Hajmohammadi (2019) explored on the relationship between internal locus of control and learner autonomy among 132 Iranian EFL learners. They found that there is a positive significant relationship between EFL learners' autonomy and their internal locus of control. The findings also revealed that EFL learners' internal locus of control can predict their level of autonomy. Due to this fact that the question of the correlation between language learning locus of control and learners' autonomy is still under-research in the context of the foreign language learning which necessitates further scholarly investigations (Peek, 2016), the present study aims at providing answer for the following research question:

$\mathrm{RQ}$ : Is there any significant correlation between EFL learners' autonomy and their internal locus of control?

\section{Method}

\subsection{Participants}

Convenience sampling was employed in the process of participant selection. The participants were 95 Iranian university EFL learners including 33 male and 62 female with the age span from 22 to 27 . They were native speakers of Persian who were majoring in Teaching English as a Foreign Language (TEFL) and English Literature. Besides, the participants' English language learning experience varied from four to seven years.

\subsection{Instruments}

\subsubsection{Learner Autonomy Perception Questionnaire (LAPQ)}

To assess EFL learners' autonomy, the Learner Autonomy Perception Questionnaire, originally devised and validated by Van Nguyen and Habók (2021), was applied. The instrument comprises 87 items using a 5-point Likert scale, ranging from 1 ("Strongly disagree") to 5 ("Strongly agree"). To ensure the reliability of the questionnaire, an internal reliability (Cronbach's alpha) was conducted by Van Nguyen and Habók (2021) and the results indicated the coefficient of 0.90 which shows acceptable and high levels of internal consistency.

\subsubsection{Internal Locus of Control Index}

For measuring the participants' internal locus of control, Internal Locus of Control Index developed by Duttweiler (1984), was employed. The instrument comprises 28 items using a 5-point Likert scale, ranging from 1 ("Rarely") to 5 ("Usually"). The internal consistency reliability index for the questionnaire was calculated by Duttweiler (1984), and the results revealed the coefficient of 0.85 that is acceptable indices of reliability. 


\subsection{Procedures}

Data collection was started by distributing the online version of the two questionnaires among a group (Telegram group) of EFL learners and they were asked to read each questionnaire carefully and respond to it. The group consisted of $240 \mathrm{EFL}$ learners and only 114 questionnaires had been filled. Besides, 19 questionnaires were discarded because they were left blank or incomplete. It must be mentioned that if there was misunderstanding concerning the questionnaires, the researcher explained the concepts in the Persian (the learners' native language). Then, data analysis was performed by means of the Statistical Package for the Social Sciences (SPSS), version 21.

\section{Results}

The research question of the present study was "Is there any significant correlation between EFL learners' autonomy and their internal locus of control?". A Pearson product moment correlation was run to answer the research question. Table 1 presents the results.

Table 1. Correlation between Learner Autonomy and Internal Locus of Control

\begin{tabular}{llcc}
\hline & & Internal Locus of Control & Learner Autonomy \\
\hline \multirow{2}{*}{ Internal Locus of control } & Pearson Correlation & 1 & $.203^{*}$ \\
\cline { 2 - 4 } & Sig. (2-tailed) & & .049 \\
\cline { 2 - 4 } & $\mathrm{N}$ & 95 & 95 \\
\hline \multirow{2}{*}{ Learner Autonomy } & Pearson Correlation & $.203^{*}$ & 1 \\
\cline { 2 - 4 } & Sig. (2-tailed) & .049 & 95 \\
\cline { 2 - 4 } & $\mathrm{N}$ & 95 & 95 \\
\hline
\end{tabular}

${ }^{\star}$. Correlation is significant at the 0.05 level (2-tailed).

As Table 1 illustrates, the Pearson correlation analysis indicates significant positive correlation between the variables $(r=0.203, p<0.05)$. As a result, there was a positive significant correlation between EFL learners' autonomy and their internal locus of control.

\section{Discussion}

The research question deals with EFL learners' autonomy and internal locus of control which was assessed through two questionnaires. To address the research question, a correlational analysis was run and the findings revealed a positive significant relationship between Iranian EFL learners' autonomy and their internal locus of control. Accordingly, the findings were found to be similar to previous studies (Aghayani \& Hajmohammadi, 2019; Peek, 2016; Saadat et al., 2012), whose study revealed positive significant correlation between EFL learners' autonomy and internal locus of control. However, there are some differences between the present study and the previous studies. For example, the participants in Aghayani and Hajmohammadi (2019) study were 132 Iranian EFL learners and they used the learner autonomy questionnaire (developed by Zhang \& Li, 2004) to assess EFL learners' autonomy which is different from this study. In another study, Peek (2016) implied his study in the context of multilingual learners and the total number of the participants were 841 who came from all over the world ( 80 different countries) whereas participants of the present study were Iranian EFL learners. Finally, Saadat et al. (2012) used different questionnaires to measure the participants' internal locus of control and selfesteem, as the manifestation of learner autonomy, in addition, the participants in their study were more than present study.

\section{Conclusion}

The main purpose of current study was to determine whether there is significant correlation between EFL learners' autonomy and their internal locus of control. One important conclusion that could be drawn from this study, based on the findings, is that there is a positive significant correlation between EFL learners' autonomy and their internal locus of control. The present study shed a cognitive and psychological light on learners' autonomous language learning in terms of EFL learners' internal locus of control. On the whole, it can be concluded that learner autonomy and internal locus of control can be considered as one of the most influential factors that have significant effect on EFL learners.

The literature accumulated on learners' autonomy introduce the concept as a western notion whose application to Eastern societies and educational contexts with cultural and social considerations is not possible, such a conclusion is drawn mainly due to considering the development and formation of learners' autonomy as an affected factor by imposed external conditions (Chan, Spratt, \& Humphreys, 2002; Kamberi, 2013), this is primarily understood when Benson (2013), clearly states that the formation and development of learners' autonomy largely depends on external factors such as living in a society in which autonomy and freedom are respected and truly valued. However, the present study aims at analysing 
the relationship between EFL learners' autonomy and their internal locus of control, instead of considering autonomy as a dependent variable totally affected by external factors; on the other hand examining the effect of internal locus of control on Iranian EFL learners as Asian learners of Eastern society, reveals top priority of internal or external factors on learners' autonomy, and thus implies the possibility of applying the notion of autonomy to Eastern EFL classes.

Due to the crucial role of autonomy and internal locus of control on EFL learners' achievement, this study assists the syllabus designers in giving particular attention and being more aware of learners' autonomy and consider how to design elements that impact EFL learners' internal locus of control. Moreover, the findings of the current study might provide valuable help to EFL teachers who seek the significance of internal locus of control and learner autonomy in language learning process through pedagogical intervention in the EFL classrooms. The present study, due to the recursive nature of any research, needs complementing by other subsequent research endeavors to arrive at more general results. Accordingly, the underlying suggestions might be implementing on the part of other studies: 1) Future studies could carry out the same study among children; 2) This study explored the correlation between learner autonomy and internal locus of control among EFL learners, another study could carry out same study among students in other field of study; 3) Future studies may consider the participant demographics (e.g., educational level, age, and gender).

\section{References}

Aghayani, B., \& Hajmohammadi, E. (2019). Internal locus of control as a predictor of EFL learners' autonomy. Asian Journal of Applied Linguistics, 6(2), 185-196.

Aghayani, B., \& Soleimani, H. (2016). Locus of control, self-regulation, and vocabulary acquisition. Germany: Lambert Academic Publishing.

Al Mulhim, E. N. (2021). Flipped learning, self-regulated learning and learning retention of students with internal/external locus of control. International Journal of Instruction, 14(1), 827-846. https://doi.org/10.29333/iij.2021.14150a

Amini, A. (2013). The impact of religiosity and locus of control on language achievement. The Iranian EFL Journal, 44(2), $70-79$

Arkavazi, S., \& Nosratinia, M. (2018). Self-regulation and locus of control predicting EFL learners' willingness to communicate. Theory and Practice in Language Studies, 8(8), 1094-1103.

Benson, P. (2013). Teaching and researching autonomy (2nd ed.). London: Routledge.

Cascio, M., Botta, V., \& Anzaldi, V. (2013). The role of self efficacy and internal locus of control in online learning. Journal of e-learning and Knowledge Society, 9(3), 95-106.

Chan, V., Spratt, M., \& Humphreys, G. (2002). Autonomous language learning: Hong Kong tertiary students' attitudes and behaviors. Evaluation \& Research in Education, 16(1), 1-18. https://doi.org/10.1080/09500790208667003

Chang, L. Y. H. (2020). Taiwanese EFL Language Teachers' Beliefs and Actual Practices Related to Learner Autonomy. TESL-EJ, 23(4), 1-15.

Duttweiler, P. C. (1984). The internal control index: A newly developed measure of locus of control. Education and Psychological Measurement, 44(2), 209-221. https://doi.org/10.1177/0013164484442004

Ghonsooly, B., \& Elahi Shirvan, M. (2011). On the relation of locus of control and L2 reading and writing achievement. English Language Teaching, 4(4), 234-244.

Hill, R. (2011). Teach internal locus of control: A positive psychology app. Harvard Girl Word Services

Huang H. (2020) Learner autonomy and responsibility: Self-learning through a flipped online EFL course. In Freiermuth M. \& Zarrinabadi N. (Eds.), Technology and the psychology of second language learners and users. New language learning and teaching environments. Palgrave Macmillan. https://doi.org/10.1007/978-3-030-34212$\underline{8} 8$

Irgin, P. \& Öz, H. (2020). EFL learners' locus of control and translation achievement. ELT Research Journal, 9(2), 219232.

Judy Shih, H. C. (2021). The use of individual and collaborative learning logs and their impact on the development of learner autonomy in the EFL classroom in Taiwan. Innovation in Language Learning and Teaching, 15(3), 195209. https://doi.org/10.1080/17501229.2020.1737703 
Kamberi, L. (2013, April). Promoting learner autonomy in foreign language learning by using student journals. In Annual International Interdisciplinary Conference 2013, Azores, Portugal, (pp. 408-412).

Katirayifar, A. A., \& Rezvani, E. (2017). The effects of Iranian EFL learners' locus of control (external vs. internal) on their test anxiety and test scores. International Journal of Research, 6(4), 57-66.

Khoshsima, H., \& Izadi, M. (2015). Creativity in Writing: A Study of EFL Learners' Locus of Control. International Journal of Applied Linguistics and English Literature, 4(2), 81-90.

Koban-Koç, D., \& Koç, S. E. (2016). Understanding learner autonomy through cognitive, metacognitive and social strategies used by English language learners in a computer-based classroom. The Journal of Language Teaching and Learning, 6(2), 58-69.

Kuluşaklı, E., \& Yumru, H. (2020). The effect of the explicit strategy training on learner autonomy. International Online Journal of Education and Teaching (IOJET), 7(2), 622-634.

Latha, G, \& Vijayalakshmi, P. (2020). Locus of control and entrepreneurial role stress. Our Heritage, 68(61), 44-49.

Melvina, M., \& Julia, J. (2021). Learner autonomy and English proficiency of Indonesian undergraduate students. Cypriot Journal of Educational Sciences, 16(2), 803-818. https://doi.org/10.18844/cjes.v16i2.5677

Myartawan, I. P. N. W., Latief, M. A., \& Suharmanto, S. (2013). The correlation between learner autonomy and English proficiency of Indonesian EFL college learners. Teflin Journal, 24(1), 63-81.

Naseri, F., \& Ghabanchi, Z. (2014). The relationship between self-efficacy beliefs, locus of control and reading comprehension ability of Iranian EFL advance learners. International Journal of Language Learning and Applied Linguistics World, 5(1), 156-174.

Nejabati, N. (2014). The effect of locus of control training on EFL students' reading comprehension. International Journal of English language Education, 2(1), 187-192.

Ningsih, S., \& Yusuf, F. N. (2021, April). Analysis of teachers' voices of learner autonomy in EFL online learning context. In Thirteenth Conference on Applied Linguistics (CONAPLIN 2020) (pp. 556-561). Atlantis Press.

Nowicki, S. (2016). Choice or chance; understanding your locus of control. Prometheus Books.

Peek, R. (2016). Exploring learner autonomy: Language learning locus of control in multilinguals. International Journal of Multilingualism, 13(2), 1-19. https://doi.org/10.1080/14790718.2015.1090991

Reich, J. W., \& Infurna, F. J. (2017). Perceived control 50 years of innovation and another 50 to go. In J. W. Reich, \& F. J. Infurna (Eds.), Perceived control theory, research, and practice in the first 50 years (pp. 2-20). Oxford University Press.

Saadat, M., Ghasemzadeh, A., Karami, S., \& Soleimani, M. (2012). Relationship between self-esteem and locus of control in Iranian University students. Procedia - Social and Behavioral Sciences, 31, 530-535. https://doi.org/10.1016/i.sbspro.2011.12.099

Soleimani, H., Aghayani, B., \& Ashari, N. (2018). The relationship among EFL learners' self-regulation, locus of control, and preference for vocabulary acquisition. Applied Linguistics Research Journal, 2(1), 12-25. https://doi.org/10.14744/alri.2018.08208

Stewart, T. (2012). Undergraduate honors service-learning \& effects on locus of control. Journal of Service-Learning in Higher Education, 1, 70-86.

Teng, M. F. (2019). Autonomy, agency, and identity in teaching and learning English as a foreign language. Singapore: Springer.

Van Nguyen, S., \& Habók, A. (2021). Designing and validating the learner autonomy perception questionnaire. Heliyon, 7(4), e06831. https://doi.org/10.1016/..heliyon.2021.e06831

Yagcioglu, O. (2015). New approaches on learner autonomy in language learning. Procedia - Social and Behavioral Sciences, 199, 428-435. https://doi.org/10.1016/j.sbspro.2015.07.529 